\title{
Edukasi jalan pagi dan latihan slow deep breathing untuk menurunkan hipertensi pada kelompok ibu pemberdayaan kesejahteraan keluarga (PKK) di Desa Bangsri Kabupaten Jepara
}

\author{
Noor Laela Fitria ${ }^{*}$, Isnaini Herawati ${ }^{2}$, Farid Rahman ${ }^{3}$ \\ 1,2,3Progam Studi Profesi Fisioterapi, Fakultas Ilmu Kesehatan, \\ Universitas Muhammadiyah Surakarta \\ *Email: noorlaela.fitria@gmail.com
}

\begin{abstract}
ABSTRAK
Hipertensi menjadi silent killer karena pada sebagaian besar kasus tidak menunjukkan gejala apapun hingga pada suatu hari hipertensi menjadi stroke dan serangan jantung yang mengakibatkan penderitanya meninggal. Hipertensi terkait erat dengan masalah psikologis dan emosional, terutama dalam tekanan hidup yang berat. Upaya penanganan pada penderita hipertensi yang dapat dilakukan yaitu dengan cara jalan pagi. Jalan pagi mampu mendorong jantung bekerja secara optimal dan dapat meningkatkan aktivitas pernapasan. Upaya penanganan lain pada hipertensi yaitu dengan cara terapi komplementer. Salah satu bentuk terapi komplementer yang menggunakan teknik relaksasi adalah latihan slow deep breathing. Metode pengabdian masyarakat ini dengan pemberian penyuluhan kepada Kelompok Ibu PKK yang bertujuan untuk manambah pengetahuan terkait jalan pagi dan latihan slow deep breathing untuk menurunkan hipertensi. Jalan pagi dapat dilakukan setiap pagi dan latihan slow deep breathing dilakukan sebanyak 6 kali permenit selama 10 menit. Pengabdian masyarakat ini dilakukan di Desa Bangsri Kabupaten Jepara dan didapatkan hasil yaitu meningkatnya pengetahuan kelompok tersebut tentang jalan pagi dan latihan slow deep breathing untuk menurunkan hipertensi dengan hasil 79\% (baik) pada nilai rata-rata pre-test dan post-test sehingga masyarakat dapat melakukan latihan tersebut dengan mandiri.
\end{abstract}

Kata kunci: hipertensi; jalan pagi;latihan slow deep breathing; kelompok ibu pkk

\section{Morning walk education and slow deep breathing exercise to reduce hypertension in pkk group in Bangsri Village, Jepara Regency}

\begin{abstract}
Hypertension is a silent killer because in most cases it does not cause any symptoms until occur stroke and heart attack which causes the sufferer to die. Hypertension is associated with psychological and emotional problems, especially under the heavy pressures of life. Treatment efforts in patients with hypertension that can be done is by walking in the morning. Morning walks can encourage the heart to work optimally and can increase respiratory activity. Another treatment for hypertension is by means of complementary therapy. One form of complementary therapy that uses exercise relaxation techniques that is slow deep breathing. This community dedication method is to provide counseling to the PKK Group which aims to manage knowledge related to morning walks and slow deep breathing exercises to reduce hypertension. Morning walks can be done every morning and slow deep breathing exercises are done 6 times per minute for 10 minutes. This community service was carried out in Bangsri Village, Jepara Regency and the results were increased knowledge of the group about morning walks and slow deep breathing exercises to reduce hypertension with $79 \%$ (good) results on the average pre-test and post-test so that people could do the exercise independently.
\end{abstract}

Keywords: hypertension;morning walk; pkk group ;slow deep breathing exercise 


\section{PENDAHULUAN}

Perubahan kondisi lingkungan berpengaruh pada pola kehidupan masyarakat, dari pola hidup tradisional ke pola kehidupan modern. Pola kehidupan modern yang menuntut serba cepat, didukung dengan meningkatnya teknologi yang menghasilkan barang dan alat serba otomatis mengakibatkan perubahan kebiasaan hidup menjadi kurang gerak dan santai. Akibat perubahan pola kebiasaan hidup yang santai dan pola makan yang menjurus pada sajian siap santap dengan kandungan lemak, protein dan garam tinggi namun rendah serat, membawa konsekuensi terhadap berkembangnya penyakit degeneratif seperti obesitas, diabetes melitus, penyakit jantung koroner (PJK), kanker, osteoporosis dan hipertensi.

Hipertensi menjadi silent killer karena pada sebagaian besar kasus tidak menunjukkan gejala apapun hingga pada suatu hari hipertensi menjadi stroke dan serangan jantung yang mengakibatkan penderitanya meninggal. Hipertensi merupakan salah satu penyakit kronis yang terkait dengan kualitas hidup, faktor risikonya seperti aktivitas fisik dan stres. Hipertensi terkait erat dengan masalah psikologis dan emosional, terutama dalam tekanan hidup yang berat (Sumartini \& Miranti, 2019). Upaya penanganan pada penderita hipertensi yang dapat dilakukan yaitu dengan cara jalan pagi. Jalan pagi mampu mendorong jantung bekerja secara optimal dan dapat meningkatkan aktivitas pernapasan (Aji, 2015).
Upaya penanganan lain pada hipertensi yaitu dengan cara terapi komplementer. Salah satu bentuk terapi komplementer yang menggunakan teknik relaksasi adalah latihan slow deep breathing. Bernapas secara perlahan dan dalam, menggunakan otot diagfragma, sehingga memungkinkan abdomen terangkat perlahan dan dada mengembang penuh. Menurut penelitian yang dilakukan Mason et al., (2013), latihan slow deep breathing memberi pengaruh terhadap saturasi oksigen menjadi meningkat, peningkatan respon sensitivitas baroreflex dan penurunan tekanan darah.

Di Indonesia, hasil Riset Kesehatan Dasar (Riskesdas) pada tahun 2018 menunjukkan prevalensi hipertensi secara nasional mencapai $34,1 \%$ (Bagaskara et al., n.d.). Berdasarkan Profil Kesehatan Kabupaten Jepara pada tahun 2014, hipertensi di Jepara masih menempati proporsi terbesar dari seluruh Penyakit Tidak Menular (PTM) yang dilaporkan yaitu sebesar $57,7 \%$ dan urutan kedua ditempati oleh diabetes mellitus (DM) sebesar $14,97 \%$. Besarnya proporsi ini hampir sama dengan proporsi tingkat Provinsi Jawa Tengah. Angka ini menunjukkan bahwa kejadian penyakit hipertensi di Kabupaten Jepara tidaklah sedikit (Profil Kesehatan Kabupaten Jepara, 2014). Berdasarkan latar belakang diatas, maka penulis tertarik untuk melakukan pengabdian masyarakat dengan konsep edukasi jalan pagi dan latihan slow deep breathing untuk menurunkan 
hipertensi pada kelompok ibu PKK di Desa Bangsri Kabupaten Jepara yang bertujuan untuk manambah pengetahuan terkait hal tersebut sehingga masyarakat dapat melakukan latihan tersebut dengan mandiri.

\section{METODE PELAKSANAAN}

Metode yang diberikan adalah dengan mengadakan penyuluhan tentang edukasi jalan pagi dan latihan slow deep breathing untuk menurunkan hipertensi yang dibantu oleh pengurus PKK Desa Bangsri Kabupaten Jepara sehingga masyarakat dapat melakukan latihan tersebut dengan mandiri.

\section{a. Pra Kegiatan}

1) Proses perijinan dimulai dengan membuat surat ijin dari universitas ditujukan kepada pengurus komunitas terkait tempat pengabdian dilakukan untuk melaksanakan program, sekaligus meminta bantuan kepada pengurus dalam program sosialisasi dan pelatihan.

2) Persiapan tempat dilakukan di rumah ketua PKK Desa Bangsri Kabupaten Jepara

3) Persiapan bahan dan perlengkapan dalam program ini mulai dari karpet, leaflet, kuesioner, daftar hadir peserta dan buku beserta bolpoin.

\section{b. Pelaksanaan Kegiatan}

Pelaksanaan kegiatan dibagi menjadi 6 sesi, yaitu:

1) Sesi pertama, berisi kata pembukaan dari pengurus
PKK dan dilanjutkan oleh mahasiswa. Mahasiswa menyampaikan alasan dan tujuan diberikan penyuluhan sambil membagikan leaflet.

2) Sesi kedua, ibu-ibu PKK diberikan soal pre-test untuk dikerjakan.

3) Sesi ketiga, berisi tentang penyuluhan ranah kerja fisioterapi.

4) Sesi keempat, berisi penyuluhan tentang pengertian, faktor risiko, gejala hipertensi, jalan pagi dan latihan slow deep breathing untuk menurunkan tekanan darah.

5) Sesi kelima, ibu-ibu PKK diberikan soal post-test untuk dikerjakan.

6) Sesi keenam, berisi tentang tanya jawab antara mahasiswa dan ibu-ibu PKK. Ibu-ibu dipersilahkan menanyakan yang belum jelas dan belum diketahui kepada mahasiswa. 


\section{HASIL DAN PEMBAHASAN}

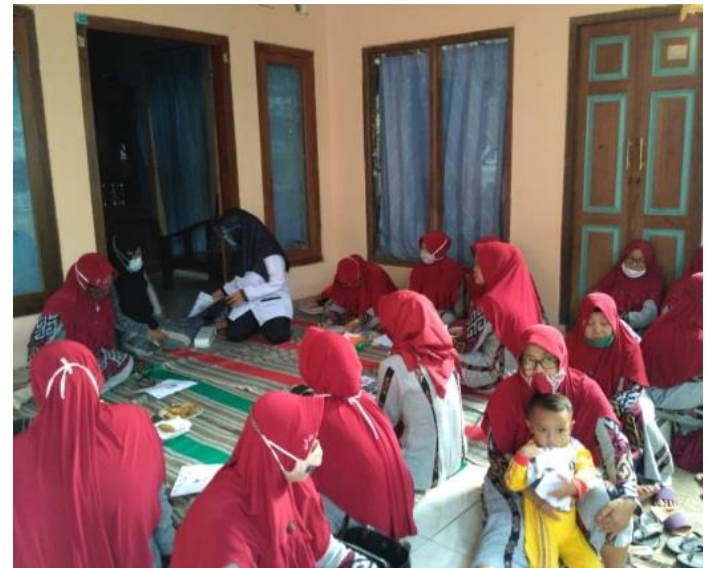

Gambar 1: Penyuluhan Kepada Kelompok Ibu PKK

Pengabdian ini dilaksanakan pada 16 November 2020 dengan peserta yang berjumlah 27 orang yaitu ibu-ibu PKK dengan usia di atas 40 tahun. Tahap pertama yang dilakukan adalah menjawab soal pre-test, pembagian leaflet, dilanjut dengan penyuluhan tentang jalan pagi dan slow deep breathing. Setelah itu melakukan demontrasi untuk teknik breathing yang digunakan. Semua peserta yang ikut dalam pelatihan ini secara aktif dan antusias melakukan demontrasi dan mereka saling bergantian untuk mempraktikkan latihan slow deep breathing. Tahap terakhir adalah menjawab soal post-test yang akan menentukan seberapa besar pemahaman peserta tentang apa yang didapatkan selama penyuluhan. Hasil penyuluhan kelompok PKK Desa Bangsri Kabupaten Jepara dapat dilihat pada data dibawah ini:
Tabel 1: Hasil Nilai Pre-Test

\begin{tabular}{|lc|}
\hline Nilai & Pre-Test \\
\hline Terendah & 2.6 \\
\hline Tertinggi & 7.3 \\
\hline Rata-rata & 5.2 \\
\hline
\end{tabular}

Tabel 2: Hasil Nilai Post-Test

\begin{tabular}{|ll|}
\hline Nilai & Post-Test \\
\hline Terendah & 8 \\
\hline Tertinggi & 10 \\
\hline Rata-rata & 9.3 \\
\hline
\end{tabular}

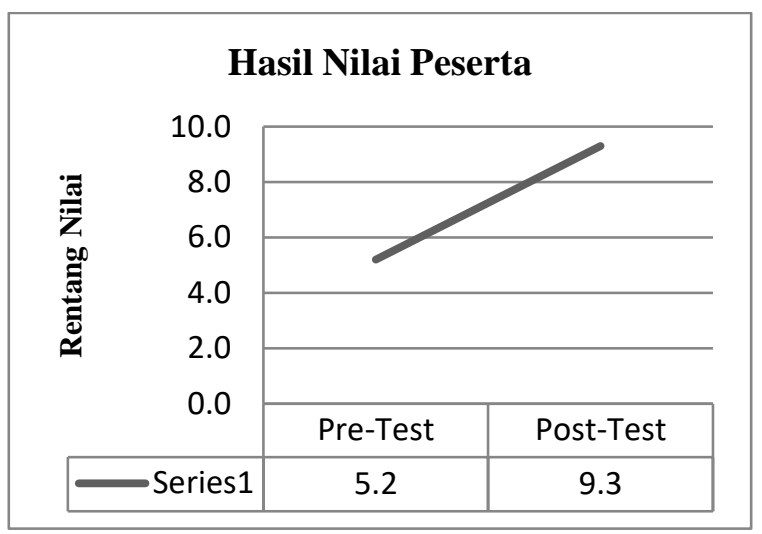

Gambar 2: Grafik Hasil Nilai Rata-Rata

Berdasarkan tabel 1 dan 2 dapat dilihat nilai tertinggi pada nilai pre-test adalah 7.3 dan nilai post-test adalah 10. Nilai terendah pada nilai pre-test adalah 2.6 dan nilai post-test adalah 8.0. Rata-rata nilai pre-test sebesar 5.2 dan nilai post-test sebesar 9.3. Data grafik di atas menunjukkan bahwa terdapat peningkatan pada nilai rata-rata pre-test dan post-test. 
Tabel 3: Hasil Persentase berdasarkan Tingkat Pengetahuan

\begin{tabular}{|lll|}
\hline Nilai Rata-Rata & Hasil \\
\hline Pre-Test & Post-Test & Persentase \\
\hline $\mathbf{5 . 2}$ & 9.3 & $79 \%$ \\
\hline & Keterangan & Baik \\
\hline
\end{tabular}

Diketahui bahwa interpretasi dari hasil peningkatan nilai rata-rata peserta berdasarkan tingkat pengetahuan adalah $0-25 \%$ yang berarti buruk, 26-50\% yang berarti kurang, $51-75 \%$ yang berarti cukup dan $76-100 \%$ yang berarti baik. Tabel 3 menunjukkan bahwa hasil peningkatan nilai rata-rata dari pre-test dan post-test adalah sebesar $79 \%$ yang dapat dikategorikan baik. Maka dari itu terdapat peningkatan nilai post-test dari nilai pre-test untuk semua responden yang mengikuti kegiatan penyuluhan. Peningkatan pengetahuan ibu-ibu PKK tentang penyakit hipertensi dan cara pencegahannya dapat menjadi acuan dalam kehidupan sehari-hari. Dilihat dari respon peserta yang sudah dapat melakukan latihan slow deep breathing secara mandiri dan antusias peserta dalam mengajukan pertanyaan. Media leaflet yang digunakan dalam penyuluhan, biasanya akan membantu mempermudah seseorang dalam memahami isi dari materi yang disampaikan. Oleh karena itu apabila materi yang disampaikan oleh pembicara kurang jelas maka peserta dapat membaca sendiri dari leaflet yang diberikan. Selanjutnya peserta dapat meminta penjelasan dengan mengajukan pertanyaan apabila kurang jelas. Namun demikian, untuk menanamkan pengetahuan yang baik tentang kesehatan dalam hal ini penyakit hipertensi dan cara pencegahannya maka dapat dilakukan dengan konsultasi kesehatan secara perorangan.

\subsection{Hipertensi}

Menurut WHO, hipertensi merupakan faktor risiko utama untuk penyakit kardiovaskuler (CVD), penyebab utama morbiditas dan mortalitas di seluruh dunia. Komplikasi hipertesi dapat terjadi pada otak, mata, jantung hingga ginjal. Hipertensi merupakan suatu gangguan pada pembuluh darah yang mengakibatkan aliran darah yang membawa suplai oksigen dan nutrisi terhambat sampai jaringan yang membutuhkannya (Nurachmah \& Gayatri, 2013).

Penyakit ini bertanggung jawab terhadap tingginya biaya pengobatan dikarenakan alasan tingginya angka kunjungan ke dokter, perawatan di rumah sakit dan / atau penggunaan obat jangka panjang. Hipertensi merupakan faktor resiko atau penyakitpenyakit kardiovaskular yang merupakan penyebab kematian tertinggi di Indonesia. Di Amerika hipertensi menimpa sekitar 65 juta dan sejumlah besar individu lainnya di dunia. Karena penyakit ini biasanya menyerang tanpa tanda-tanda, makanya sering disebut sebagai "silent killer" (Herawati, 2016).

The Eighth Report of the Joint National Committee on Prevention, Detection, Evaluation and Treatment of High Blood Pressure (JNC 8) mengklasifikasikan tekanan darah 
dikatakan normal dengan tekanan sistolik/diastolik $\quad 120 / 80 \quad \mathrm{mmHg}$, prehipertensi untuk 120-139/80-89 mmHg, hipertensi tingkat 1 untuk 140159/90-99 mmHg dan hipertensi tingkat 2 untuk $\geq 160 / 100 \mathrm{mmHg}$. Menurut Kayce Bell \& June Twiggs, (2015) berbagai faktor meningkatkan risiko seseorang untuk terjadi hipertensi, seperti kondisi kesehatan, gaya hidup, dan riwayat keluarga. Beberapa faktor risiko seperti riwayat keluarga, tidak dapat dikendalikan. Namun, ada beberapa faktor risiko seperti kurang berolahraga, obesitas dan stress dapat dikendalikan untuk mengurangi kemungkinan pasien terjadi hipertensi.

\subsection{Jalan Pagi}

Melakukan aktivitas fisik jalan pagi secara teratur akan menurunkan tekanan darah. Menurut Hidayat, (2011) bahwa aktivitas yang teratur dapat mengurangi tekanan darah pada usia tua dengan membantu mempertahankan elastisitas pembuluh darah. Selain itu, aktivitas fisik yang teratur mengajarkan tubuh untuk mendistribusikan darah dengan baik ke otot pada saat berjalan. Sehingga lebih mengurangi beban kerja jantung. Perubahan ini berfungsi menurunkan denyut jantung dan tekanan darah pada saat aktivitas fisik. Karena kebutuhan otot jantung akan oksigen berkaitan dengan denyut jantung dan tekanan darah.

Jalan pagi mampu mendorong jantung bekerja secara optimal, dimana olahraga untuk jantung mampu meningkatkan kebutuhan energi oleh sel, jaringan dan organ tubuh, maka dari itu aktivitas pernapasan dan otot rangka akan meningkat. Akibat peningkatan aktivitas pernapasan, aliran balik vena, volume sekuncup dan curah jantung meningkat sehingga tekanan darah arteri meningkat sedang. Setelah itu akan terjadi fase istirahat yang dapat menurunkan aktivitas pernapasan dan otot rangka sehingga aktivitas saraf simpatis dan epinefrin menurun. Saraf parasimpatis akan aktif memperlambat denyut jantung, volume sekuncup menurun dan vasodilatasi vena. Akibatnya curah jantung menurun dan resistensi perifer total juga mengalami penurunan sehingga terjadinya penurunan tekanan darah (Aji, 2015).

\subsection{Latihan Slow Deep Breathing}

Latihan slow deep breathing merupakan teknik relaksasi yang disadari berfungsi untuk mengatur pernapasan secara dalam dan lambat, menggunakan otot diagfragma, sehingga memungkinkan abdomen terangkat perlahan dan dada mengembang penuh. Latihan slow deep breathing dilakukan sebanyak 6 kali permenit selama 10 menit memberi pengaruh terhadap tekanan darah melalui peningkatan sensitivitas baroreseptor dan menurunkan aktivitas sistem saraf simpatis serta meningkatan aktivitas sistem saraf parasimpatis pada penderita hipertensi primer (Vasuki \& Sweety, n.d.).

a. Latihan pernapasan dengan teknik bernapas secara perlahan dan dalam, menggunakan otot diagfragma, sehingga memungkinkan 
abdomen terangkat perlahan dan dada mengembang penuh. Dosis yang diberikan, sebagai berikut:

1) Frequency: 2 kali dalam sehari,

2) Intensity: 6 kali per menit

3) Time: 10 menit

4) Type: breathing exercise

b. Teknik latihan slow deep breathing:

1) Atur responden dengan posisi duduk,

2) Kedua tangan responden diletakkan diatas perut,

3) Anjurkan melakukan napas secara perlahan dan dalam melalui hidung,

4) Tarik napas selama 5 detik, rasakan abdomen mengembang saat menarik napas,

5) Kerutkan bibir, keluarkan melalui mulut dan hembuskan napas secara perlahan selama 5 detik. Rasakan abdomen bergerak ke bawah (Vasuki \& Sweety, n.d.).

\section{KESIMPULAN}

Program pengabdian ini bermanfaat untuk kelompok komunitas terutama kepada pengurus komunitas karena dapat membuat pelaksanaan program baru dalam komunitas yang dapat dilaksanakan setelah kegiatan rutin. Progam penyuluhan ini untuk memberikan edukasi kepada komunitas tentang jalan pagi dan pemberian latihan slow deep breathing untuk menurunkan hipertensi.
Kegiatan pengabdian masyarakat ini berjalan dengan baik dan lancar sesuai yang di jadwalkan. Pada saat kegiatan pengabdian ini peserta komunitas sangat berantusias terhadap hal ini terlihat dari beberapa peserta yang bertanya, mengikuti gerakan dan demonstrasinya. Hasil yang didapatkan dari nilai pre-test dan post-test yaitu adanya peningkatan pengetahuan atau pemahaman tentang penyuluhan jalan pagi dan latihan slow deep breathing untuk menurunkan hipertensi pada kelompok Ibu PKK Desa Bangsri Kabupaten Jepara.

\section{REFERENSI}

Aji. (2015). Pengaruh Senam Aerobik Terhadap Penurunan Tekanan Darah Di Posyandu Gunung Kidul Yogyakarta. Keperawatan Universitas 'Aisyiyah Yogyakarta.

Bagaskara, R. G., Simanjuntak, D. R., \& Suryanegara, W. (N.D.). Hubungan Obesitas Dengan Kejadian Hipertensi Pada Individu Usia $\geq 18$ Tahun Di Indonesia (Analisis Lanjutan Data Riskesdas 2018). 7.

Herawati, I. (2016). Manfaat Latihan Pengaturan Pernafasan Untuk Menurunkan Tekanan Darah Pada Penderita Hipertensi Primer. 9.

Hidayat. (2011). Pengantar Konsep Keperawatan. Salemba Medika.

Kayce Bell \& June Twiggs. (2015). Hypertension: The Silent Killer: $\quad$ Updated Jnc-8 
Guideline Recommendations. Continuing Education.

Mason, H., Vandoni, M., Debarbieri, G., Codrons, E., Ugargol, V., \& Bernardi, L. (2013). Cardiovascular And Respiratory Effect Of Yogic Slow Breathing In The Yoga Beginner: What Is The Best Approach? Evidence-Based Complementary And Alternative Medicine, 2013, 17.

Https://Doi.Org/10.1155/2013/ 743504

Nurachmah, E., \& Gayatri, D. (2013). Penurunan Tekanan Darah Pada Pasien Hipertensi Melalui Brisk Walking Exercise. Jurnal Keperawatan Indonesia, 16(1), 7.
Profil Kesehatan Kabupaten Jepara Tahun 2014. (2014). Pemerintah Kabupaten Jepara. Sumartini, N. P., \& Miranti, I. (2019). Pengaruh Slow Deep Breathing Terhadap Tekanan Darah Lansia Hipertensi Di Puskesmas Ubung Lombok Tengah. Jurnal Keperawatan Terpadu (Integrated Nursing Journal), $\quad 1(1), \quad 38$. Https://Doi.Org/10.32807/Jkt. V1i1.26

Vasuki, G., \& Sweety, L. (N.D.). The Study Of Usefulness Of Deep Breathing Exercise On Blood Pressure In Pre- Hypertensive And Hypertensive Patients. Indian Journal of Clinical Anatomy And Physiology, 4. 